\title{
INFORMAL BY-LAW AMENDMENT BY INCONSISTENT EMPLOYMENT CONTRACTS
}

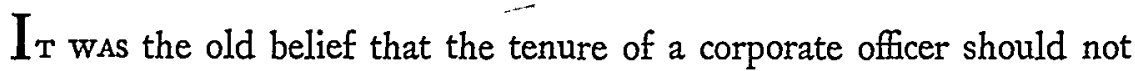
extend too far beyond the term of the current board of directors, for it was feared that the holdover officers might hamper subsequent directors in the execution of their policy making function. ${ }^{x}$ This belief is yielding ${ }^{2}$ to the view that a better policy is served by allowing corporations to attract able executives with long term employment contracts. This transition in policy has been made in many states with the assistance of a statutory amendment authorizing long term employment contracts for corporate officers, but permitting the corporation to retain the one year limitation on tenure by an appropriate provision in the charter or by-laws. ${ }^{3}$ Such a statutory provision has found its way into the Model Business Corporation Act $\S 4(\mathrm{k})$ which, as Texas Business Corporation Act art. 2.02, ${ }^{4}$ was involved in Dixie Glass Co. v. Pollak. ${ }^{5}$

The Dixie Glass Company, a closely held Texas corporation, had availed itself of its statutory power to limit the terms of its officers to one year by by-law provision. ${ }^{6}$ Nevertheless, all of the company's officers, directors, and shareholders in joint annual meeting had awarded one of their officers, ${ }^{7}$ the plaintiff in this action, a five year employment contract. ${ }^{8}$ The Texas Supreme Court had recently decided ${ }^{9}$ that a

\footnotetext{
${ }^{2}$ See generally O'NeAL, Close Corporations ch. vi (1958).

${ }^{2}$ See generally Note, I 09 U. PA. L. Rev. 224 ( 1961 ).

${ }^{3}$ An example is the 195 I amendment to article 1327 of the Texas statutes, TEX. REv. Civ. STAT. art. I327 (Supp. 1952).

“TEx. Bus. CoRp. ACT ANN. art. 2.02A (1956). "Each corporation shall have power: ... (12) to elect or appoint officers and agents of the corporation for such period of time as the corporation may determine, and define their duties and fix their compensation." The words "for such period of time as the corporation may determine" do not appear in the Model Act, but it is believed that these words add nothing save emphasis.

${ }_{5} 34$ I S.W.2d 530 (Tex. Civ. App. r960).

${ }^{8}$ Dixie Glass Co. v. Pollak, supra note 5, at 534 .

TThe office in question was that of comptroller, one not generally considered to be encompassed within the statutory designation "corporate office." It seems significaut that the court could have upheld the validity of the employment contract by finding, as the plaintiff urged in the alternative, that the comptroller was not one of the officers whose tenure is limited to one year by the by-laws. Rather, the court assumed that the comptroller was an officer within the prohibition of the by-laws and that the by-law had been informally amended.

${ }^{3}$ The contract further gave the plaintiff an option to renew for three additional
} 
by-law limiting the tenure of a given corporate office to one year "by necessary implication" limited contracts of employment in that office to one year. ${ }^{10}$ Therefore, if the plaintiff in the Dixie case was to hold the company liable for damages in breach of contract, ${ }^{11}$ he first had to establish the validity of a contract that was clearly inconsistent with the by-laws. ${ }^{12}$

The by-laws of the defendant corporation further provided for their alteration or repeal by a majority vote of the directors or stockholders. ${ }^{13}$ The court upheld the validity of the plaintiff's contract, stating that, ${ }^{14}$ "If the stockholders and directors can change or amend a by-law, they may waive its application in a given case." In the peculiar facts of this case, both the directors and stockholders unanimously approved the

five-year periods, a weekly salary of $\$ 200$, and an annual bonus of $10 \%$ of net profits. Dixie Glass Co. v. Pollak, 34I S.W.2d 530, 532 (rg60).

${ }^{\circ}$ See Pioneer Specialties Inc. v. Nelson, 339 S.W.2d 199 (Tex. 1960), in which the Texas Supreme Court overruled this same appellate court which had upheld a two year employment contract for the corporate president inconsistent with a by-law requiring annual election of officers. The appellate court's theory had been that the language of the statute indicated a distinction between "election" and "employment."

${ }^{20}$ The dissent in this case, Pioneer Specialties v. Nelson, supra note 9, at 201, suggested a resolution of the dilemma described in the first paragraph of this casenote, i.e., how to attract able executives by long term employment security without entrenching a possible bad choice in a position of control. The dissenting judges suggested that the man selected to fill a statutory office be elected for one year or at the will of the directors and that he then be given a long term employment contract to perform perfunctory clerical duties at a salary and other benefits commensurate with tbe elected office. Thereafter the man could be removed from his statutory office with little or no breach of contract liability if the best interests of the company so demanded and yet the officer would be assured of a stipulated salary. The defect of this plan from the company's point of view is the necessity of paying two salaries for one office if the first officer under such contract were replaced. The weakness from the potential officer's point of view is that to retain an influential office is part of the consideration to a man rising in the management field. Demotion may not only affect his luster as a coming executive, but also his financial return if, as part of his salary, he receives stock options or a percentage of profits which he hopes to make more valuable by his efforts in the office.

${ }^{21}$ Upon trial the jury had found that the plaintiff had been dismissed without good cause, Dixie Glass Co. v. Pollak, 34I S.W.2d 530, 552 (Tex. Civ. App. 1960).

${ }^{12}$ The possible argument that mere election to office, even without a contract makes the company liable to the officer for expected benefits is thwarted by TEX. Bus. Corp. ACT art. 2.43A ( $\times 956$ ), which provides that "election or appointment of an officer or agent shall not of itself create contract rights."

${ }^{13}$ The by-laws of the Dixie Glass Company at Section xviii as set out in the Dixic opinion, supra note II, at 535, "All by-laws of the company shall be subject to alteration or repeal, and new by-laws may be made, either by the affirmative vote of the holders of record of a majority of the outstanding stock of the company . . . or by the affirmative vote of a majority of the whole Board of Directors . ..."

${ }^{14}$ Dixie Glass Co. v. Pollak, 341 S.W.2d 530, 536 (Tex. Civ. App. 1960). 

found and the by-law is held not amended, but superseded pro tanto, or waived, as to the particular transaction. ${ }^{18}$ When found waived, the by-law remains absolutely unimpaired and any subsequent inconsistent contract will be subject to it unless such subsequent contract also amounts to a waiver.

Whether the theory be waiver or amendment, the courts cannot uphold the contract vis à vis the by-law unless the directors not only have the power to amend, but the power to amend informally. The directors have power to amend informally when they have power to change and thus disregard not only the by-law, but the amending procedure as well. Whether the directors possess this power turns on two considerations; whether the charter or by-laws set out the amending procedure and who, if anyone, has a valid expectancy that the amending procedure not be changed without his consent.

The power to amend and the prescribed method of exercising that power may be embodied in the corporate charter or the by-laws. If the corporate charter prescribes the method of amending the by-law, the directors cannot amend or waive ${ }^{19}$ except in substantial compliance with the prescribed method. ${ }^{20}$ If the method of amending the by-laws

had for many years since functioned under three directors, the court found that "the by-law requiring a board of five was changed by the unanimous (implied) consent of the stockholders . . . the act of incorporation being silent as to the number of directors, and the statute . . . being satisfied with a board of that number." Buck v. Troy Aqueduct Co., 76 Vt. 75, 77, 56 Atl. 285,286 (1903).

18 "I am of the opinion and find that the contract made by the defendants pursuant to the express authority of its board of directors, which had express power to amend at will the by-laws of the defendant, modified, in its legal effect, all inconsistent by-laws and prevails over them." Realty Acceptance Corp. v. Montgomery, 51 F.2d 636, 639 (3d Cir. 1930). See Community Stores, Inc. v. Dean, I Terry 566, I4 A.2d 623 (Del. 1940); Mathews v. Fort Valley Cotton Mills, 179 Ga. 580, 176 S.E. 505 (1934); Hill v. American Co-op. Ass'n, 195 La. 590, I97 So. 241 (1940); Pomeroy v. Westaway, 273 App. Div. 760, 70 N.Y.S.2d 449 (App. Div. 1947). See generally FlETCHER, Corporations $\$ 4200$ (perm. ed. 1931); MACHEN, Corporations $\$ 728$ (1908).

That the by-laws contain a clause prescribing a formal amending procedure does not, of itself, preclude the possibility of waiver by inconsistent contract. See generally, Annot., 169 A.L.R. 1374 (1947), and cases cited therein.

${ }^{10}$ Moreover, statute and charter provisions expressly forbidding waiver have been upheld. McCurry v. The Practorians, Inc, 90 S.W.2d 853 (Tex. Civ. App. 1936); Sovereign Camp, W.O.W. v. Todd, 283 S.W. 659 (Tex. Civ. App. 1926).

${ }^{20}$ Tapo Citrus Ass'n v. Casey, 45 Cal. App. 2d 796, I15 P.2d 203 (1941); Powers v. Marine Engineer's Benevolent Ass'n 52 Cal. App. 511 , 199 Pac. 353 (1921); Moon v. Moon Motor Car Co., I 7 Del. Ch. 176, 151 Atl. 298 (1930); J. P. Lamb \& Co. v. Merchant's Nat'l Mut. Fire Ins. Co., 18 N.D. 253, I19 N.W. 1048 (1909).

Unless the charter provision is considered to be in the nature of a contract with the state, the directors can waive a by-law in spite of a prescribed amending procedure in 
is set out in the by-laws themselves, many courts have answered the question of whether the directors can disregard the procedure by determining whether the directors or the stockholders have original power to adopt by-laws. ${ }^{21}$ If the directors adopted the original by-laws or if the stockholders adopted the original by-laws and then delegated the power to amend to the directors without specific directives as to how the power should be exercised, these courts hold that the directors ${ }^{22}$ need not strictly adhere to the amending procedure set out in the by-law. ${ }^{23}$ Otherwise, the directors have power to amend only by the prescribed procedure. The real relevancy of these considerations lies in their bearing on the question of the extent to which the by-law constitutes a contract establishing the relationship between the stockholders and the directors or among the stockholders inter se. If the by-law is found to be in the nature of a contract, the stockholders have a vested right that the amending procedure be strictly adhered to..$^{24}$ But if the by-law was drawn merely to expedite the handling of business, no one can object that the directors saw fit to disregard the suggested procedure. $^{25}$

the charter, if the shareholders knew all the material facts and acquiesced in the violation. Here we see the amendment theory at the next higher level. If the stockholders can unilaterally amend the charter, they can, under proper circumstances, amend it (except to the extent that it is a public record) by implication when they acquiesce in director violations. This acquiescence may be formal or implied by the acceptance by the corporation of benefits derived from the violation. In other words, the stockholders can waive their right that the directors not waive the by-law informally. Underhill v. Santa Barbara Land, Bldg. \& Improvement Co., 93 Cal. 200, 28 Pac. 1049 (1892).

${ }_{21}$ TEx. Bus. CoRP. ACT art. 2123 (I956), vests power to adopt by-laws in the stockholders unless and to the extent that the incorporators vest this power in the directors by the terms of the articles of incorporation.

${ }^{23}$ Dorens v. Supreme Lodge Knights of Pythias, 75 Miss. 466, 23 So. I9I (1898); Richardson v. Union Congregational Soc'y, 58 N.H. 187 (1877); Smith v. Nelson, 18 Vt. 5 II (I846); see generally Annot., I69 A.L.R. I374 (I947), to the effect that the director's power to waive the by-laws informally is not vitiated by the mere existence of a formal amending procedure in the by-laws.

${ }^{23}$ See Cohen v. Camden Refrigerating \& Terminals Co., I29 N.J.L. 5I9, 30 A.2d 428 ( ( 943 ).

${ }_{24}$ Loewenthal v. Rubber Reclaiming Co., 52 N.J. Eq. 440, 28 Atl. 454 (I 894 ) (calling such by-law "fundamental by-laws"). If the by-law is in the nature of a contract, the stockholder may be found to have a property right that the by-law be amended only by the prescribed method of amending, Schood v. Hotel Easton Co., 369 Pa. 486, 87 A.2d 227 (1952).

${ }^{25}$ Whether a by-law is in the nature of a contract or more in the nature of an operating procedure for the convenience of the directors is a question of fact in the establishment of which consideration should be given to the intent with which the framers instituted the by-law. See generally Fretcher, Corporations \$ 4r95 (perm. ed. I93x). 
Once decided that the directors have power to amend the by-laws and to do so without strict adherence to a prescribed formality, the courts must turn to the question of the intent with which the directors approved the contract. It is generally held that the directors must have been aware of the facts that afford pertinency to the by-law ${ }^{26}$ and must have intended that the contract affect the legal rights of the corporation in the manner it did before they can be said to have waived the by-law. ${ }^{27}$ To illustrate, if the directors of the Dixie Glass Company had negligently made a five year contract thinking that it was for only one year, the inconsistent by-law would not have been waived and the contract would not have been binding. But there is another and seemly overconceptualistic view that a contract made with knowledge of an inconsistent by-law will be held subject to the by-law on the theory that one who contracts with knowledge of a by-law is conclusively presumed to have intended to incorporate its terms into the contract. ${ }^{28}$ Officers, stockholders, and others who were "insiders" at the time the contract was executed, like the plaintiff in the Dixie case, are charged with constructive notice of the contents of the by-laws. ${ }^{29}$ "Outsiders," however, can enforce their contracts against the company unless they contracted with actual knowledge of the inconsistent by-law. ${ }^{30}$

There are several cogent reasons for caution in the recognition of informal amendment or waiver of the by-laws by contract. When the formal amending procedure is disregarded, the policy behind the offended by-law is less likely to be examined and weighed against the values to be derived from the proposed contract. ${ }^{31}$ Furthermore, if one of the directors is not present when the contract is voted upon, especially if he is entitled to notice when an amendment to the by-laws is contemplated, he is denied an opportunity to be heard and to gain support for adherence to the by-law. To say that the absent director

\footnotetext{
${ }^{28}$ Clapton v. Chandler, 27 Cal. App. 595, 150 Pac. rorz (1915); Blair v. Modern Woodmen of America, 282 Ill. App. 36, 94 S.W.2d 156 (1935); Supreme Tent Knights of Maccobees of the World v. Altman, 134 Mo. App. ${ }_{363}, 1_{14}$ S.W. I107 (1908).

${ }^{27}$ Underhill v. Santa Barbara Land, Bldg. \& Improvement Co., $93 \mathrm{Cal} .300,28$ Pac. 1044 (1892). (1943).

${ }^{28}$ Cohen v. Camden Refrigerating \& Terminals Co., 129 N.J.L. 519,30 A.2d 428,

${ }^{20}$ Jones v. Vance Shoe Co., 92 Ill. App. 158 (1900); Millar v. Grieb, $276 \mathrm{~Pa}$. 372, 120 Atl. 390 (1923).

${ }^{30}$ Cherokee Public Service Co. v. Harry Cragin Lumber Co., I 74 Okla. 67, 49 P.2d 723 (1935). See generally Fletcher, Corporations $\$ 4199$ (perm. ed. 1931).

${ }^{31}$ See generally O'NEAL, ClOSE CORPorations $\$ 8.02$ (1958).
} 
waived his right to be heard discounts the fact that the corporation is denied the benefit of his views on the proposed action.

Nevertheless, the need for giving validity to informal amendment by contract seems to outweigh the possible dangers. Many of the arguments against informal amendment should be directed to the questionable wisdom of by-laws amendable by a simple plurality of the directors. $^{32}$ Moreover, as long as small businesses must operate under the same corporation statutes that serve large, public-issue corporations, some consideration must be given to the small corporation's peculiar need for quick, convenient and inexpensive director action. ${ }^{33}$ Many businessmen who utilize the corporate form do not appreciate the need for formality and others simply refuse to perform seemingly non-productive ritual. The placing of a premium on corporate formality serves only to render uncertain the validity of the informal procedures inevitably utilized by small businessmen.

Two months before the Dixie case was heard, the Texas Supreme Court reversed this same appellate court on a very similar fact situation and held the employment contract to be invalid. In that case ${ }^{34}$ it does not appear that the theory of informal amendment by inconsistent contract, successful in the Dixie case, was urged. If the Dixie case comes before the Texas Supreme Court on appeal, it would clarify the law and serve the needs of business for that court to recognize the concept of informal amendment. However, the court should circumscribe its application to situations where the directors have full power to amend and to amend informally, where the directors intended that the corporation be bound in the way the contract is interpreted, and where undue violence is not done to the status of the by-laws within accepted corporate norms.

${ }^{32}$ "The evil possibilities suggested have their true foundations not in the supremacy of contract over by-law, but in the futility of a limitation which rests solely upon a by-law amendable by a majority of the board." Realty Acceptance Corp. v. Montgomery, 5 I F.2d 636, 639 (3d Cir. 1930).

${ }^{33}$ See generally O'NEAL, Close CoRporations $\$ \S$ I.12-1.15 (I958).

34 Pioneer Specialties Inc. v. Nelson, 339 S.W.2d 199 (Tex. 1960), summarized in note 9 supra. 


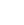

